\title{
KONSEP NEGARA DEMOKRASI
}

\author{
ANNISA HUMAIRA \\ annisahumaira299@gmail.com \\ 2010003600199 \\ Universitas Eka Sakti
}

\section{A. PENDAHULUAN}

Indonesia merupakan negara yang memiliki ribuan pulau atau disebut juga dengan negara kepulauan, banyaknya pulau kecil dan pulau besar yang ada di Indonesia. Dengan keadaan negara yang banyak pulau atau disebut juga dengan negara kepulauan ini terjadinya keadaan geografis. Keadaan yang geografis ini menyebabkan terjadinya heterogenitas masyarakat yang hidup menyebar di pulau yang ada di Indonesia. Keadaan heterogenitas atau juga disebut dengan keadaan kemajemukan masyarakat secara vertikal nampak pada masyarakat yang hidup dengan adanya kelas-kelas atau lapisan-lapisan masyarakat. Dengan keadaan masyarakat yang heterogenitas di Indonesia maka diperlukannya undang-undang yang mengatur kehidupan berbangsa dan bernegara secara menyeluruh agar tidak terjadinya perbedaaan kelas-kelas atau lapisan-lapisan yang ada di Indonesia. Dalam hal ini untuk menjamin hak-hak individu atau masyarakat dalam berbagai keberagaman. Keadaan heterogenitas masyarakat Indonesia secara horizontal, secara horizontal dapat dilihat dengan dari keanekaragaman suku bangsa dengan nilai serta adat istiadat yang terkandung dalam suku dan budaya yang ada di masyarakat di Indonesia.

Agar terjamin perlindungan hak individu dalam kehidupan bermasyarakat dan bernegara di Indonesia pada umumnya diatur dalam Undang-undang Dasar (UUD) atau konstitusi yang ada di Indonesia. Konstitusi merupakan semua ketentuan,peraturan,atau perundang-undangan,termasuk didalamnya yaitu 
Undang-undang sendiri, konstitusi bertujuan untuk memberikan pembatasan sekaligus pengawasan terhadap kekuasaan politik yang ada di suatu negara tersebut. Tujuan dari konstitusi ini yaitu untuk membatasi kekuasaan penguasa sehingga tidak melakukan tindakan yang merugikan masyarakat yang ada,konstitusi juga bertujuan agar melepaskan kontrol kekuasaan dari penguasaan sendiri.

Undang-undang Dasar (UUD) ditempatkan sebagai peraturan tertinggi dalam kehidupan bernegara merupakan pencerminan pelaksanaan negara hukum atau rechstaat disebut juga dengan rule of law. Unsur rechsstaat yang pada umumnya dimuat dalam Undang undang Dasar (UUD) meliputi hak-hak manusia,pemisahan atau pembagian kekuasaan untuk menjamin hak,pemerintah berdasarkan peraturan-peraturan dan peradilan administrasi dalam perselisihan. Sedangkan unsur rule of law yang hampir sama posisinya dengan rechtstaat meliputi supremasi aturan-aturan hukum,kedudukan yang sama menghadapi hukum dan terjaminnya hak-hak manusia oleh undang-undang.

Aturan hukum tertinggi dalam sebuah negara adalah konstitusi atau Undang-undang Dasar (UUD). Karena konstitusi di dalamnya mengatur mengenai pembatasan kekuasaan. Karena itu pula, konstitusi menjadi sangat penting untuk menjamin hak-hak asasi warga negara sehingga tidak terjadinya perlakuan yang sewenang wenang dari pemerintah yang kekuasaannya yang dibatasi. Selain itu di dalam negara hukum terdapat aturan aturan hukum sebagai penjabaran UUD yang melindungi hak asasi warga negara. Salah satu hak asasi warga negara yang harus dilindungi yaitu hak setiap individu untuk mengeluarkan pendapat,baik secara lisan maupun secara tertulis. Jaminan hak mengeluarkan pendapat merupakan manifestasi kehidupan demokrasi. 
Demokrasi merupakan sistem pemerintahan dengan mengedepankan kedaulatan rakyat. Demokrasi adalah keadaan negara dengan sistem pemerintahnya mengakui kedaulatan berada ditangan rakyat,kekuasaan tertinggi berada dalam keputusan bersama rakyat berkuasa, pemerintah rakyat dan kekuasaan oleh rakyat. Demokrasi sebagai kekuasaan pokoknya diakui dan berasal dari rakyat dan kerena itu rakyatlah yang sebenarnya menentukan dan memberi arah serta menyelenggarakan kehidupann yang kenegaraan. Sebagai dasar hidup bernegara, demokrasi memberikan pengertian bahwa pada tingkat terakhir rakyat merasakan langsung manfaat dari demokrasi yang di laksanakan. Rakyat berhak menikmati demokrasi sebab hanya dengan demikianlah arah kehidupan yang lebih adil dalam aspek kehidupan. Maka dari itu. Negara demokrasi yaitu negara yang berlandaskan kehendak dan kemauan rakyat,karena kedaulatan berada ditangan rakyat

\section{B. PEMBAHASAN}

Kata demokrasi berasal dari bahasa Yunani,yaitu Demos yang artinya rakyat dan Kratos yang berarti kekuasaan. Demokrasi menurut Lincoln yaitu bahwa demokrasi merupakan sistem pemerintahan yang diselenggarakan dari rakyat,oleh rakyat,dan untuk rakyat. Demokrasi merupakan sistem pemerintahan yang telah digunakan di berbagai negara termasuk di Indonesia. Salah satu negara yang menganut demokrasi yaitu ciri-cirinya adanya kebebasan pers dan media, adanya persamaan hak bagi semua warga negara,adanya pemilihan umum langsung serta pemerintah yang ada ditangan rakyat.

Sistem pemerintah demokrasi memiliki dua bentuk yaitu adanya demokrasi langsung dan demokrasi tidak langsung. Demokrasi langsung yaitu demokrasi dimana setiap rakyat memberikan suara atau pendapat dalam menentukan suatu keputusan. 
Setiap rakyat mewakili dirinya sendiri untuk memilih suatu kebijakan sehingga mereka memiliki pengaruh terhadap keadaan politik yang terjadi. Sistem demokrasi langsung digunakan pada masa awal terbentuknya demokrasi di Athena ketika terdapat suatu permasalah yang harus diselesaikan,seluruh rakyat berkumpul untuk membahasnya. Diera modern sistem demokrasi langsung menjadi tidak praktis karena umumnya populasi suatu negara cukup besar dan mengumpulkan seluruh rakyat dalam suatu forum merupakan hal yang sangat sulit,dalam demokrasi langsung ini menuntut partisipasi yang tinggi dari rakyat sedangkan rakyat modern cenderung tidak memiliki waktu untuk mempelajari semua permasalah yang ada. Banyaknya kekurangan demokrasi langsung ini apabila dianut di masa modern ini salah satunya, waktu dan biaya anggaran yang cukup mahal atau tinggi,sering terjadinya konflik sosial horizontal yang terjadi di masyarakat dikarenakan elit politik yang tak memperdulikan,dan sulitnya diterapkan pada negara yang memiliki warga negara yang cukup banyak. Demokrasi tak langsung merupakan paham demokrasi yang dilaksanakan melalui sistem perwakilan. Corak pemerintahan demokrasi yang dilakukan melalui badan perwakilan rakyat yang dipilih oleh rakyat dan bertanggung jawab kepada rakyat. Penerapan demokrasi tak langsung ini biasanya dilakukan oleh negara yang jumlah penduduknya semakin banyak,wilayahnya semakin luas dan permasalahan yang dihadapi semakin rumit.

Prinsip-prinsip demokrasi dan prasyarat dari berdirinya negara demokrasi telah terakomodasi dalam konstitusi negara kesatuan republik Indonesia. Prinsip- prinsip demokrasi,dapat dilihat dari pendapat Almadudi yang kemudian dikenal sebagai “soko guru demokrasi” menurutnya prinsip-prinsip demokrasi yaitu :

1. Kedaulatan rakyat.

2. Pemerintahan berdasarkan persetujuan dari perintah 
3. Kekuasaan mayoritas

4. Hak hak minoritas

5. Jaminan hak asasi manusia

6. Pemilihan yang bebas, adil dan jujur

7. Persamaan didepan hukum

8. Proses hukum yang wajar

9. Pembatasan pemerintah serta konstitusional

10. Pluralisme sosial,ekonomi,dan politik

11. Nilai nilai toleransi,pragmatisme, kerjasama dan mufakat

Tujuan dari demokrasi adalah untuk menciptakan kehidupan masyarakat yang sejahtera,adil dan makmur dengan konsep yang mengedepankan keadilan,kejujuran dan keterbukaan.pada konsepnya tujuan demokrasi dalam kehidupan bernegara juga meliputi kebebasan berpendapat dan kedaulatan rakyat. Ada beberapa tujuan dari demokrasi yaitu Memberikan kebebasan dalam berpendapat dan berekspresi, mencegah perselisihan antar kelompok, menciptakan keamanan dan ketertiban bersama,mendorong masyarakat aktif dalam pemerintahan, membatasi kekuasaan pemerintah.

Demokrasi dibedakan dari sudut pandang tugas-tugas dan hubungan antara alat-alat perlengkapan negara yaitu ada beberapa :

1. Demokrasi dengan sistem parlementer,yakni dalam demokrasi ini terdapat hubungan erat antara badan legislatif dengan badan eksekutif, hanya badan eksekutif yang biasa disebut "kabinet" dipimpin oleh seorang perdana menteri yang dibentuk berdasarkan dukungan suara terbanyak yang dapat dalam dewan perwakilan rakyat atau parlemen. 
2. Demokrasi dengan sistem pemisah kekuasaan yakni demokrasi dalam arti kekuasaan dipisahkan menjadi kekuasaan legislatif,eksekutif dan yudikatif Demokrasi dengan sistem referendum yakni demokrasi perwakilan dengan kontrol rakyat secara langsung terhadap wakil-wakilnya di dewan perwakilan rakyat,ada 2 macam referendum yakni referendum obligator dan referendum fakultatif. Dalam referendum obligator kebijakan atau undang undang yang diajukan oleh pemerintah atau dibuat dewan perwakilan rakyat dapat dijalankan setelah disetujui oleh rakyat dengan suara terbanyak. Referendum fakultatif, undang undang yang dibuat dewan perwakilan rakyat baru diminta persetujuan rakyat, apabila dalam jangka waktu tertentu setelah undang-undang diumumkan sejumlah rakyat memintanya.

Konsep demokrasi yang ada Indonesia merupakan demokrasi pancasila yang memiliki ciri khusus yang sesuai dengan ideologi negara pancasila yakni adanya musyawarah dan mufakat. Musyawarah sendiri berawal dari sila yang keempat pancasila. Musyawarah merupakan salah satu nilai luhur dari bangsa Indonesia yang dikenal di semua daerah yang ada di Indonesia meskipun dengan istilah yang berbeda-beda tidak salah musyawarah menjadi utama dari demokrasi pancasila. Musyawarah sebagai proses mempertemukan seluruh pihak untuk membicarakan suatu masalah atau memperbincangkan suatu rencana merupakan sangat ideal untuk mewujudkan suatu keputusan yang baik dan sejalan dengan kepentingan para anggota masyarakat. Demokrasi Indonesia lebih mengedepankan musyawarah mufakat, hal ini dapat dilihat dari proses pengambilan keputusan baik dari desa sampai pusat,Indonesia menjunjung tinggi musyawarah mufakat bukan mayoritas. Dengan adanya musyawarah ini secara langsung telah melibatkan masyarakat dalam penyelenggaraan pemerintah.Saat ini sistem demokrasi yang dipandang paling baik di 
dunia, hal ini dikarenakan sistem demokrasi hampir sebagai asas fundamental dalam memfasilitasi peran masyarakat dalam menyelenggarakan pemerintah.

\section{PENUTUP}

Negara demokrasi merupakan negara yang menganut bentuk atau mekanisme sistem pemerintahan dengan mewujudkan kedaulatan rakyat atas negara untuk dijalankan oleh pemerintah negara tersebut. Demokrasi selalu berhubungan dengan hak asasi manusia. Upaya untuk menegakan demokrasi merupakan upaya umat manusia dalam rangka menjamin dan melindungi hak asasi,karena demokrasi merupakan salah satu sistem politik yang memberi penghargaan atas hak dasar manusia. Demokrasi bukanlah hanya sebatas hak sipil dan politik rakyat,namun dalam perkembangannya demokrasi juga berkaitan erat dengan sejauh mana terjaminnya hak-hak ekonomi dan sosial budaya dan rakyatnya. Dengan demikian hak asasi manusia kan terwujud dan terjamin oleh negara yang demokratis dan demikian sebaliknya,demokrasi akan terwujud apabila negara mau menjamin tegaknya hak asasi manusia. Prinsip demokrasi atau kedaulatan rakyat juga dapat menjamin peran serta masyarakat dalam proses pengambilan keputusan, sehingga setiap perturan perundang-undangan yang diterapkan dan ditegakkan benar-benar mencerminkan perasaan keadilan masyarkat hukum dan peraturan perundang-undangan tidak boleh ditetapkan dan diterapkan secara sepihak oleh atau hanya untuk kepentingan penguasa saja. 


\section{DAFTAR PUSTAKA}

Darmini Roza dan Laurensius Arliman S Peran Pemerintah Daerah Di Dalam Melindungi Hak Anak Di Indonesia, Masalah-Masalah Hukum, Volume 47, Nomor 1, 2018.

Laurensius Arliman S, Komnas HAM dan Perlindungan Anak Pelaku Tindak Pidana, Deepublish, Yogyakarta, 2015.

Laurensius Arliman S, Penguatan Perlindungan Anak Dari Tindakan Human Trafficking Di Daerah Perbatasan Indonesia, Jurnal Selat, Volume 4, Nomor $1,2016$.

Laurensius Arliman S, Problematika Dan Solusi Pemenuhan Perlindungan Hak Anak Sebagai Tersangka Tindak Pidana Di Satlantas Polresta Pariaman, Justicia Islamica, Volume 13, Nomor 2, 2016.

Laurensius Arliman S, Pelaksanaan Perlindungan Anak Yang Tereksploitasi Secara Ekonomi Oleh Pemerintah Kota Padang, Veritas et Justitia, Volume 2, Nomor $1,2016$.

Laurensius Arliman S, Kedudukan Ketetapan MPR Dalam Hierarki Peraturan Perundang-Undangan Di Indonesia, Lex Jurnalica, Volume 13, Nomor 3, 2016.

Laurensius Arliman S, Komnas Perempuan Sebagai State Auxialiary Bodies Dalam Penegakan Ham Perempuan Indonesia, Justicia Islamica, Volume 14, Nomor $2,2017$.

Laurensius Arliman S, Peranan Pers Untuk Mewujudkan Perlindungan Anak Berkelanjutan Di Indonesia, Jurnal Ilmu Hukum Tambun Bungai, Volume 2, Nomor 2, 2017.

Laurensius Arliman S, Mewujudkan Penegakan Hukum Yang Baik Untuk Mewujudkan Indonesia Sebagai Negara Hukum, Jurnal Hukum Doctrinal, Volume 2, Nomor 2, 2017.

Laurensius Arliman S, Participation Non-Governmental Organization In Protecting Child Rights In The Area Of Social Conflict, The 1st Ushuluddin and Islamic Thought International Conference (Usicon), Volume 1, 2017.

Laurensius Arliman S, Partisipasi Masyarakat Dalam Pembentukan PerundangUndangan Untuk Mewujudkan Negara Kesejahteraan Indonesia, Jurnal Politik Pemerintahan Dharma Praja, Volume 10, Nomor 1, 2017, https://doi.org/10.33701/jppdp.v10i1.379.

Laurensius Arliman S, Peran Komisi Perlindungan Anak Indonesia Untuk Mewujudkan Perlindungan Anak, Jurnal Respublica Volume 17, Nomor 2, 2018. 
Laurensius Arliman S, Menjerat Pelaku Penyuruh Pengrusakan Barang Milik Orang Lain Dengan Mempertimbangkan Asas Fungsi Sosial, Jurnal Gagasan Hukum, Volume 1, Nomor 1, 2019.

Laurensius Arliman S, Ilmu Perundang-Undangan Yang Baik Untuk Negara Indonesia, Deepublish, Yogyakarta, 2019.

Laurensius Arliman S, Isdal Veri, Gustiwarni, Elfitrayenti, Ade Sakurawati, Yasri, Pengaruh Karakteristik Individu, Perlindungan Hak Perempuan Terhadap Kualitas Pelayanan Komnas Perempuan Dengan Kompetensi Sumber Daya Manusia Sebagai Variabel Mediasi, Jurnal Menara Ekonomi: Penelitian dan Kajian Ilmiah Bidang Ekonomi, Volume 6, Nomor 2, 2020.

Laurensius Arliman S, Pendidikan Kewarganegaraan, Deepublish, Yogyakarta, 2020.

Laurensius Arliman S, Makna Keuangan Negara Dalam Pasal Pasal 23 E Undang-Undang Dasar 1945, Jurnal Lex Librum, Volume 6, Nomor 2 Juni 2020, http://dx.doi.org/10.46839/1ljih.v6i2.151.

Laurensius Arliman S, Kedudukan Lembaga Negara Independen Di Indonesia Untuk Mencapai Tujuan Negara Hukum, Kertha Semaya Journal Ilmu Hukum, Volume 8, Nomor 7, 2020.

Laurensius Arliman S, Pelaksanaan Assesment Oleh Polres Kepulauan Mentawai Sebagai Bentuk Pelaksanaan Rehabilitasi Bagi Pecandu Dan Korban Penyalahgunaan Narkotika, Jurnal Muhakkamah, Volume 5, Nomor 1, 2020.

Laurensius Arliman S, Aswandi Aswandi, Firgi Nurdiansyah, Laxmy Defilah, Nova Sari Yudistia, Ni Putu Eka, Viona Putri, Zakia Zakia, Ernita Arief, Prinsip, Mekanisme Dan Bentuk Pelayanan Informasi Kepada Publik Oleh Direktorat Jenderal Pajak, Volume 17, No Nomor, 2020.

Larensius Arliman S, Koordinasi PT. Pegadaian (Persero) Dengan Direktorat Reserse Narkoba Polda Sumbar Dalam Penimbangan Barang Bukti Penyalahgunaan Narkotika, UIR Law Review, Volume 4, Nomor 2, 2020, https://doi.org/10.25299/uirlrev.2020.vol4(1).3779.

Laurensius Arliman S, Tantangan Pendidikan Kewarganegaraan Pada Revolusi 4.0, Ensiklopedia Sosial Review, Volume 2, Nomor 3, 2020.

Muhammad Afif dan Laurensius Arliman S, Protection Of Children's Rights Of The Islamic And Constitutional Law Perspective Of The Republic Of Indonesia, Proceeding: Internasional Conference On Humanity, Law And Sharia (Ichlash), Volume 1, Nomor 2, 2020.

Otong Rosadi danLaurensius Arliman S, Urgensi Pengaturan Badan Pembinaan Ideologi Pancasila Berdasarkan Undang-Undang Sebagai State Auxiliary Bodies yang Merawat Pancasila dalam Perspektif Hak Asasi Manusia, Prosiding Konferensi Nasional Hak Asasi Manusia, Kebudayaan dan Tujuan 
Pembangunan Berkelanjutan Indonesia pada Masa Pandemi Covid-19: Tantangan untuk Keilmuan Hukum dan Sosial Volume 1, Universitas Pancasila, Jakarta, 2020. 